\title{
HEARING LOSS AND VERY LOW BIRTHWEIGHT
}

\section{Silvia Borkoski Barreiro, Juan C. Falcon Gonzalez, Angel Osorio Acosta, Angel Ramos Macias}

Department of Otolaryngology, Complejo Hospitalario Universitario Insulra Materno Infantil de Gran Canaria, Las Palmas de Gran Canaria, Spain

Corresponding author: Silvia Borkoski Barreiro, Department of Otolaryngology, Complejo Hospitalario Universitario Insulra Materno Infantil de Gran Canaria, Las Palmas de Gran Canaria, Spain, e-mail: silviaborkoski@hotmail.com

\begin{abstract}
Background: Regardless of gestational age, any newborn (NB) with a weight at birth of $<1500 \mathrm{~g}$ is considered to be of very low birth weight (VLBW). The incidence of hearing loss in this population group is $5-6 \%$ but the frequency of moderate or severe hearing loss in children of VLBW is $2 \%$.

Material and methods: Retrospective study of 364 NBs with birth weight $<1500$ g. Two levels of TEOAE screening were conducted, followed by an ABR test if the initial testing was inconclusive. The SPSS statistical software package, version 20.0 for Windows, was used for statistical processing of data. Fisher's Exact Test was used to study possible associations among categorical variables.

Results: From 1 January 2007 to 31 December 2010, a total of 26,708 subjects were included in the hearing screening program. Out of these, 364 were NBs of VLBW. Out of 112 NBs with VLBW, 76 (67.8\%) had an ABR test done. Of these, 22 showed signs of hearing loss. Eight of them (36.4\%) were diagnosed with sensorioneural hearing loss (SNHL), and out of these, 2 infants had bilateral profound SNHL. The risk factor for hearing loss most frequently associated with VLBW was the use of ototoxic medications.
\end{abstract}

Conclusions: Hearing loss diagnosis among VLBW NBs is higher than the percentage in the general population. All subjects diagnosed with hearing loss were very premature infants and had one or two other auditory risk factors associated with their VLBW.

Keywords: deafness $\bullet$ sensorineural hearing loss $\bullet$ premature infant $\bullet$ neonatal screening

\section{PÉRDIDA AUDITIVA Y BAJO PESO AL NACER}

\section{Resumen}

Antecedentes: Independientemente de la edad gestacional, el bajo peso al nacer (MBPN) en un neonato (RN) es de $<1500 \mathrm{~g}$. En un $5-6 \%$ de los neonatos de este grupo hay una pérdida auditiva, mientras que en un $2 \%$ es una pérdida moderada-profunda.

Material y métodos: La prueba retrospectiva fue realizada para un grupo de $364 \mathrm{RN}$ de un peso al nacer de $<1500 \mathrm{~g}$. Se realizó una prueba de cribado TEOAE de dos fases, y después en caso de fallos, se realizó una prueba de ABR. Para el procesamiento de datos estadísticos de hizo uso de programas para realizar estadísticas SPSS, versión 20.0 para Windows. Los análisis de la relación entre las variables categóricas se realizaron con la prueba de Fishher.

Resultados: Desde el 1 de enero de 2007 hasta el 31 de diciembre de 22010 en el programa de pruebas de cribado participaron 26708 neonatos. 364 de ellos tenían MBPN. En 112 de los RN con MBPN, 76 (67,8\%) se realizó una prueba de ABR. 22 de esos neonatos tenían síntomas de pérdida auditiva. En ocho de ellos $(36,4 \%)$ se diagnosticó hipoacusia neurosensorial (HNS), mientras que 2 neonatos tenían una HNS bilateral profunda. El factor de riesgo de pérdida auditiva, muchas veces relacionada con MBPN eran fármacos otóxicos.

Conclusiones: El porcentaje de pérdidas auditivas en neonatos con MBPN es más alto que en toda la población. Cada neonato con una pérdida auditiva diagnosticada era prematuro y tenía uno u otros dos factores de riesgo relacionados con MBPN.

Palabras clave: sordera $\bullet$ hipoacusia neurosensorial $\bullet$ prematuro $\bullet$ prueba de cribado de neonatos 


\section{ТУГОУХОСТЬ И НИЗКАЯ МАССА ТЕЛА ПРИ РОЖДЕНИИ}

\section{Изложение}

Фон: Независимо от гестационного возраста, низкая масса тела при рождении (VLBW) у новорожденного (NB) составляет <1500 гр. У 5-6\% новорожденных из этой группы проявляется тугоухость, а у $2 \%$ - умеренная или глубокая тугоухость.

Материал и методы: Ретроспективное исследование было проведено для группы 364 NB с массой тела при рождении <1500 гр. Были проведены двухэтапные скрининговые исследования TЕОАЕ, а потом, в сомнительных случаях, выполнено исследование ABR. Для обработки статистических данных был использован пакет программ для ведения статистики SPSS, версия 20.0 для Windows. Анализ связи между категорическими переменными был выполнен с помощью критерия Фишера.

Результаты: С 1 января 2007 г. по 31 декабря 2010 г. в программе скрининговых исследований взяло участие 26078 новорожденных. 364 из них имело VLBW. У 112 NB c VLBW, 76 (67,8\%) выполнено исследование ABR. У 22 из этих новорожденных имелись симптомы тугоухости. У восьми из них $(36,4 \%)$ диагностирована перцептивная тугоухость (SNHL), тогда как 2 новорожденных имело двухсторонний глубокий SNHL. Факторами риска, которые часто связаывали с VLBW, являлись ототоксичные лекарственные средства.

Итоги: Процент тугоухости у новорожденных детей с VLBW выше, чем во всей популяции. Каждый новорожденный ребенок со диагностированнной тугоухостью был преждевременно рожденный и имел один или два факторы риска, связанные с VLBW.

Ключевые слова: глухота • перцептивная тугоухость • преждевременно рожденный • скрининговые исследования новорожденных

\section{NIEDOSŁUCH A NISKA MASA URODZENIOWA}

\section{Streszczenie}

Tło: Niezależnie od wieku ciążowego, niska masa urodzeniowa (VLBW) u noworodka (NB) to $<1500$ g. U 5-6\% noworodków $\mathrm{z}$ tej grupy występuje niedosłuch, natomiast u $2 \%$ jest to niedosłuch od umiarkowanego do głębokiego.

Materiał i metody: Badanie retrospektywne wykonano dla grupy $364 \mathrm{NB}$ o masie urodzeniowej $<1500$ g. Przeprowadzono dwustopniowe badania przesiewowe TEOAE, a następnie, w przypadkach wątpliwych, wykonano badanie ABR. Do przetwarzania danych statystycznych wykorzystano pakiet oprogramowania do prowadzenia statystyk SPSS, wersja 20.0 dla Windows. Analizy związku pomiędzy zmiennymi kategorycznymi dokonano za pomocą Testu Fishera.

Wyniki: Od 1 stycznia 2007 r. do 31 grudnia 2010 r., w programie badań przesiewowych udział wzięło 26708 noworodków. 364 z niech miało VLBW. U 112 NB z VLBW, 76 (67,8\%) wykonano badanie ABR. 22 z tych noworodków miało oznaki niedosłuchu. U ośmiu z nich (36,4\%) zdiagnozowano niedosłuch odbiorczy (SNHL), natomiast 2 noworodki miały obustronny głęboki SNHL. Czynnikiem ryzyka niedosłuchu, często łączonego z VLBW, były leki ototoksyczne.

Wnioski: Procent niedosłuchów u noworodków z VLBW jest wyższy niż w całej populacji. Każdy noworodek ze zdiagnozowanym niedosłuchem był wcześniakiem i miał jeden lub dwa inne czynniki ryzyka związane z VLBW.

Słowa kluczowe: głuchota • niedosłuch odbiorczy • wcześniak • badania przesiewowe u noworodków

\section{Background}

In large population screening studies conducted in Spain, USA, Australia, and England, hearing loss was the most prevalent disorder observed, affecting 5 out of 1000 newborns (NBs). In the case of profound sensorineural hearing loss (SNHL), the ratio was 1 per 1000 NBs. The criteria or risk factors associated with hearing loss were established in 1994 and revised in 2000. Between 10 and 30\% newborns meet one of these risk factors. Some programs of neonatal screening for hearing loss still consider very low birth weight (VLBW) as a risk factor for hearing loss [1-3].
Regardless of gestational period, any NB with a weight at birth $<1500 \mathrm{~g}$ is considered a NB with VLBW. Prematurity is one of the most prevalent health issues in pediatric populations in developed countries. Approximately 8 to $10 \%$ of births occur before 37 weeks of pregnancy and this is associated with $50 \%$ of cases of infant disability. NBs with very low weight account for $1-1.5 \%$ of cases.

The incidence of hearing loss in this group is $5-6 \%$, but the frequency of moderate or severe hearing loss in NBs with VLBW is $2 \%$. However, it is not clear whether the fact of weighing $<1500 \mathrm{~g}$ at birth or having a gestational period 


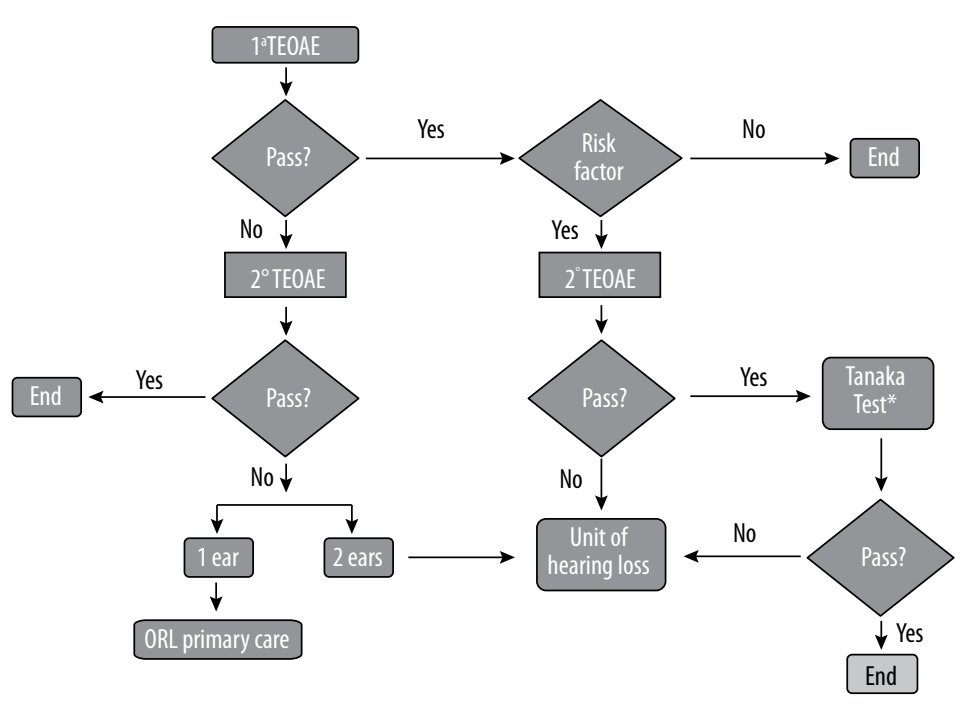

Figure 1. Protocol Universal Infant Hearing Loss Screening Program Community of Canary Islands

*Audiological child test that seeks to recognize warning signs of a child with hearing impairment.

Table 1. Risk factors for hearing loss by sex of NBs with VLBW.

\begin{tabular}{lrrrrrrr}
\hline & \multicolumn{2}{c}{ Boys } & \multicolumn{2}{c}{ Girls } & \multicolumn{2}{c}{ Total } \\
\cline { 2 - 7 } & Count & \% & Count & \% & Count & \% \\
\hline Only VLBW & 130 & 63.4 & 101 & 63.5 & 231 & 63.5 \\
\hline VLBW, ototoxic and hyperbilirubinemia & 47 & 22.9 & 33 & 20.8 & 80 & 22.0 \\
\hline VLBW, ototoxic and others & 24 & 11.7 & 25 & 15.7 & 49 & 13.4 \\
\hline VLBW, no ototoxic & 4 & 2.0 & 0 & .0 & 4 & 1.1 \\
\hline Total & $\mathbf{2 0 5}$ & $\mathbf{1 0 0 . 0}$ & $\mathbf{1 5 9}$ & $\mathbf{1 0 0 . 0}$ & $\mathbf{3 6 4}$ & $\mathbf{1 0 0 . 0}$ \\
\hline
\end{tabular}

$<32$ weeks are really risk factors by themselves, or just an added circumstance that makes them more vulnerable to hearing problems $[4,5]$.

Early detection and treatment of these problems will largely determine the quality of life of these children in the future, so regular monitoring of certain aspects is necessary, including an assessment of hearing abilities [2].

The objective of this paper is to determine SNHL incidence and identify hearing loss risk factors in NBs with VLBW included in the Universal Hearing Loss Screening Program in our hospital during the period 2007-10.

\section{Material and methods}

In total, $364 \mathrm{NBs}$ with weight at birth $<1500 \mathrm{~g}$ were included. All had tests done as part of the Universal Infant Hearing Loss Screening Program. In the Canary Islands this program is based on a universal population screening and is divided into two phases [6] (Figure 1).

The first check-up took place during the first 48 hours of life, taking advantage of the mother's hospitalization period. The detection of otoacoustic emissions was the technique of choice. Portable and automatic devices (ScreenTA Echo-Plus) were used to conduct the first test. All children were then referred to a second phase in which
Intelligent Hearing and Interacoustic systems were used to detect otoacoustic emissions. If transient-evoked otoacoustic emissions (TEOAEs) were absent in both ears, they were referred to the Hearing Loss Unit of the ENT department for diagnosis and follow-up using auditory brainstem response (ABR).

The SPSS statistical software package, version 20.0 for Windows, was used for the statistical processing of data. Fisher's Exact Test was used to study the possible associations among categorical variables. A statistical hypothesis test was considered statistically significant when the corresponding $p$-value was $<0.05$.

The Ethics Committee of the Complejo Hospitalario Universitario Insular Materno Infantil approved this study. In all cases, parents were requested to sign informed consent.

\section{Results}

During the period from 1 January 2007 to 31 December 2010, a total of 26,708 subjects were included in the hearing screening program. Of those, 364 were NBs with VLBW; 205 were boys (56.3\%) and 159 were girls (43.7\%).

Table 1 shows a breakdown of risk factors for hearing loss by gender in NBs with VLBW. 
Table 2. Hearing loss factors detected by ABR.

\begin{tabular}{lccc}
\hline & \multicolumn{2}{c}{ Hearing Loss } & Total \\
\cline { 2 - 4 } & No & Yes & \multirow{2}{*}{46} \\
\hline Only VLBW & 34 & 12 & 16 \\
\hline VLBW, ototoxic and hyperbilirubinemia & 10 & 6 & 10 \\
\hline VLBW, ototoxic and perinatal asphyxia & 7 & 3 & 3 \\
\hline VLBW, ototoxic and congenital heart disease & 2 & 1 & 1 \\
\hline VLBW, ototoxic and others & 1 & 0 & $\mathbf{2 2}$ \\
\hline Total & $\mathbf{5 4}$ & $\mathbf{2 2}$ \\
\hline
\end{tabular}

Table 3. NBs with VLBW diagnosed with SNHL using ABR.

\begin{tabular}{lcc}
\hline & & SNHL \\
\cline { 3 - 3 } & Count & of total \\
\hline Only VLBW & 4 & $3.6 \%$ \\
\hline VLBW, ototoxic and hyperbilirubinemia & 3 & $2.7 \%$ \\
\hline VLBW, ototoxic and perinatal asphyxia & 1 & $0.9 \%$ \\
\hline VLBW, ototoxic and congenital heart disease & 0 & $\mathbf{8}$ \\
\hline Total & $\mathbf{7 . 1 \%}$ \\
\hline
\end{tabular}

Table 4. Association between hearing loss and ABR separated into two groups by weeks of gestation $\left(p=0.011^{\star}\right)$.

\begin{tabular}{|c|c|c|c|c|c|}
\hline & & & \multicolumn{2}{|c|}{ Weeks of gestation } & \multirow{2}{*}{ Total } \\
\hline & & & $<32$ & $\geq 32$ & \\
\hline \multirow{4}{*}{ Hearing } & \multirow{2}{*}{ No } & Count & 42 & 12 & 54 \\
\hline & & Expected frequency ${ }^{\star *}$ & 45.5 & 8.5 & 54.0 \\
\hline & \multirow{2}{*}{ Yes } & Count & 22 & 0 & 22 \\
\hline & & Expected frequency ${ }^{* *}$ & 18.5 & 3.5 & 22.0 \\
\hline \multirow{2}{*}{ Total } & & Count & 64 & 12 & 76 \\
\hline & & Expected frequency ${ }^{\star \star}$ & 64.0 & 12.0 & 76.0 \\
\hline
\end{tabular}

* $p$-value obtained by Fisher's exact test; ${ }^{* *}$ expected frequency is estimated under the hypothesis of independence or no association between the two variables involved.

TEOAE testing performed in the first stage gave negative outcomes in $40.8 \%$ of NBs with VLBW. In the second stage, TEOAEs were absent in $15.5 \%$ of the sample. A total of $112 \mathrm{NBs}$ were referred for ABR, 64 boys (17.6\%) and 48 girls (13.2\%).

Out of the 112 NBs with VLBW, 76 (67.8\%) had an ABR test done. Out of these, 22 showed signs of hearing loss. This result was statistically significant compared to the expected percentage of the general population $(p<0.001)$. Eight (36.4\%) were diagnosed with SNHL, and of these, 2 children had bilateral profound SNHL. A difference was observed in the number of NBs with VLBW diagnosed with profound SNHL in our sample against the expected percentage in the general population, but this difference was not significant $(p>0.05)$.
Table 2 shows a breakdown of NBs with VLBW diagnosed with hearing loss using ABR and the association with other risk factors.

Table 3 shows the type of hearing loss within the group of NBs with VLBW diagnosed with hearing loss, confirmed by $\mathrm{ABR}$.

Regarding the distribution of the type of hearing loss, a total of 7 NBs had bilateral SNHL, and 1 NB had unilateral SNHL (right ear). The risk factor for hearing loss most frequently associated with VLBW was the use of ototoxic medications. The 22 NBs with VLBW diagnosed with hearing loss were very premature children, born at less than 32 weeks of gestation $(p=0.011)$; a statistically significant result (Table 4 ). 
Keep in mind, however, that 36 children (32.2\%) who were referred to the diagnostic phase did not attend it. They were rescheduled to an audiological control, discovering that $35(91.7 \%)$ of those who did not turn up for the previous test missed their appointment again. Although the reasons and characteristics of these children were not analyzed and assessed, this may influence our final results.

\section{Discussion}

Hearing loss is the most common sensory disorder among human beings. Loss of hearing not only has a permanent effect on the development of language, but also has possible implications in the educational, emotional, and social development of children $[7,8]$.

Early intervention in children with hearing loss has been shown to result in good language acquisition, taking advantage of brain plasticity during the first years of life. Early and universal detection is therefore the only reasonable strategy for early diagnosis of hearing loss in children. A study by Kraft et al. confirms that the majority of risk indicators currently recommended by the JCIH are effective at identifying children at increased risk of both congenital and delayed onset hearing loss [9-12].

The extent to which VLBW increases the prevalence of SNHL remains unclear. Several studies have concluded that the combination of risk factors and the general state of the NB is more important in the development of SNHL than low birth weight alone.

Ohl et al. [13] observed that the association of two or more risk factors significantly increases bilateral hearing loss and Maqbool concludes [14] that the incidence of hearing loss increased with the number of risk factors. In our sample, over one-fourth of NBs with VLBW had one risk factor for hearing loss associated with VLBW, the most frequent being the use of ototoxic medication $(72.7 \%)$ and the presence of hyperbilirubinemia (31.8\%). Bilateral profound SNHL was diagnosed in 2 children who also had 2 or 3 risk factors associated with VLBW.

VLBW alone is no longer considered an indicator of the risk of congenital hearing loss or later development of hearing loss, although several authors agree that being born with VLBW is one of the most frequent factors among those identified in a NB diagnosed with hearing loss [1517]. VLBW and prematurity are often concomitant, making it difficult to separate one from the other. A higher incidence of hearing loss has been observed in preterm compared to full-term NBs [15,18-20]
Very premature children ( $\leq 32$ weeks) and/or children weighing less than $1500 \mathrm{~g}$ at birth are the population group at the highest risk of SNHL. Consequently, some studies report an incidence of SNHL in this group of patients of 2 to 4 for every $100 \mathrm{NBs}[20,21]$.

Bielecki et al. refer to the coexistence of prematurity and VLBW in children diagnosed with SNHL [15]. Our results show that all children diagnosed with SNHL were born with $\leq 32$ weeks gestation and all had a combination of two or more risk factors of hearing loss associated with their VLBW, accounting for $2.2 \%$ of all the NBs studied. This data matches that from other studies [21-24] where the rate of SNHL among children who had some associated risk factor was $1-2 \%$.

It is essential that a program of early detection of hearing loss for children is able to recapture patients who, for various reasons, do not follow through or complete the screening. The percentages of loss of contact and failure to attend follow-up appointments in both screening programs for hearing loss and monitoring programs implemented by Neonatal Units for NB of VLBW are high. In a study conducted by Beswick et al. [25] it was found that children who had only the auditory risk factor had significantly higher rates of non-attendance than those with a hearing risk indicator.

In a review by Vazquez et al. regarding drop-outs in monitoring NB of VLBW [26], it was found that those who drop out of the screening process often belong to immigrant communities, tend to have a lower cultural level, or live farther from the hospital. The authors showed that these children had a higher rate of sequelae [26]. In our sample, $32 \%$ of children referred to the diagnostic phase did not attend follow-up appointments.

\section{Conclusions}

The percentage of children diagnosed with hearing loss among NBs with VLBW is $2.2 \%$, higher than the percentage expected in the general population. All of those who were diagnosed with SNHL hearing loss were very premature babies and had one or two auditory risk factors associated with their VLBW. The risk factor for hearing loss most frequently associated with VLBW was the use of ototoxic medications.

\section{Conflict of interests}

The authors declare that there is no conflict of interests.

\section{References:}

1. Puig T, Municio A, Medà C. Cribaje (screening) auditivo neonatal universal versus Cribaje (screening) selectivo como parte del tratamiento de la sordera infantil (Revisión Cochrane traducida). In: La Biblioteca Cochrane Plus, 2008 Número 2. Oxford: Update Software Ltd. Available at: dhttp: //updatesoftware.com. (Translated from The Cochrane Library, 2008 Issue 2. Chichester UK, John Wiley \& Sons, Ltd.).
2. American Academy of Pediatrics, Joint Committee on Infant Hearing. Year 2007 position statement: Principles and guidelines for early hearing detection and intervention programs. Pediatrics, 2007; 120(4): 898-21. 
3. Trinidad-Ramos G1, de Aguilar VA, Jaudenes-Casaubón C, Núñez-Batalla F, Sequí-Canet JM; Comisión para la Detección Precoz de la Hipoacusia (CODEPEH). Early hearing detection and intervention: 2010 CODEPEH recommendation. Acta Otorrinolaringol Esp. 2010; 61: 69-77 [in Spanish]

4. Torres Valdivieso MJ, Rodríguez López J, Gómez Castillo E, Bustos Lozao G, Bergas Sendin E, Pallás Alonso CR. Outcome of newborn with birth weight less than or equal to $1500 \mathrm{~g}$ and gestational age less than or equal to 32 weeks, during the 2 first years of age corrected: comparison of two time periods. An Pediatr (Barc), 2010; 72(6): 377-84.

5. Yang E, Stuart E, Mencher G, Mencher L, Vincer M. Auditory brain stem responses to air and bone conducted clicks in the audiological assessment of at risk infants. Ear Hear, 1991; 3: $175-82$.

6. Borkoski Barreiro SA, Falcón González JC, Bueno Yanes J et al. Results of an early hearing detection program. Acta Otorrinolaringol Esp, 2013; 64: 92-6.

7. Willems P. Genetic causes of hearing loss. N Engl J Med, 2000; 342: 1101-9.

8. Marco J, Almenar A, Alzina V, Bixquert V, Jaudenes MC, Ramos A et al. Quality control of an early detection, diagnosis and early intervention program for deafness in newborn. Official document of the Early Detection Commission of Deafness in Newborn (CODEPEH). Acta Otorrinolaringol Esp, 2004; 55(3): 103-6

9. Yoshinaga-Itano A, Sedey AL, Coulter DK, Mehl AL. Language of early and later identified children with hearing loss. Pediatrics, 1998; 1161-71.

10. Bailey H, Bower C, Krishnawamy J, Coates H. Newborn hearing screening in Western Australia. Med J, 2002, 177: 180-5.

11. Kraft CT, Malhotra S, Boerst A, Thorne MC. Risk indicators for congenital and delayed-onset hearing loss. Otol Neurotol, 2014; 35(10): 1839-43.

12. Driscoll C, Beswick R, Doherty E, D'Silva R, Cross A. The validity of family history as a risk factor in pediatric hearing loss. Int J Pediatr Otorhinolaryngol, 2015; 79(5): 654-9

13. Ohl Ch, Dornier L, Czajka C, Chobat J-C, Tavernier L. Newborn hearing screening on infants at risk. Int J Pediatr Otorhinolaryngol, 2009; 73: 1691-5.
14. Maqbool M, Najar BA, Gattoo I, Chowdhary J. Screening for hearing impairment in high risk neonates: a hospital based study. J Clin Diagn Res, 2015; 9(6): SC18-21.

15. Bielecki I, Horbulewics A, Wolan T. Risk factors associated with hearing loss in infants: an analysis of 5282 referred neonates. Int J Pediatr Otorhinolaryngol, 2011; 75: 925-30.

16. Nuñez Batalla F, Trinidad Ramos G, Sequí Canet JM, Alzina De Aguilar V, Jaúdenes Casaubón C. Risk factors for sensorineural hearing loss in children. Acta Otorrinolaringol Esp, 2012; 63(5): 382-90.

17. Kumar A, Shah N, Patel KB, Vishwakarma R. Hearing screening in a tertiary care hospital in India. J Clin Diagn Res, 2015; 9(3): MC01-4.

18. Cañete SO, Torrente AM. Hearing screening in infants with very low birth weight (VLBW), Padre Hurtado experience. Rev Otorrinolaringol Cir Cabeza Cuello, 2011; 71: 117-22.

19. Martines F, Salvago P, Bentivegna D, Bartolone A, Dispenza F, Martinez E. Audiologic profile of infants at risk: experience of a Western Sicily tertiary care centre. Int J Pediatr Otorhinolaryngol, 2012; 76: 1285-91.

20. van Dommelen P, Verkerk PH, van Straaten HL. Hearing loss by week of gestation and birth weight in very preterm neonates. J Pediatr, 2015; 166(4): 840-3.

21. Erenberg A, Lemons J, Sia C, TrunkelD, Ziring P. Newborn and infant hearing loss: detection and intervention. Pediatrics, 1999; 103(2): 527-30.

22. Ptok M. Early detection of hearing impairment in newborns and infants. Dtsch Arztebl Int, 2011; 108: 426-31.

23. Kanji A, Khoza-Shangase K. The occurrence of high-risk factors for hearing loss in very-low-birth-weight neonates: a retrospective exploratory study of targeted hearing screening. S Afr J Commun Disord, 2012; 59: 3-7.

24. Abu-Shaheen A, Al-Masri M, El-Bakri N, Batieha A, Nofal A, Abdelmoety D. Prevalence and risk factors of hearing loss among infants in Jordan: initial results from universal neonatal screening. Int J Audiol, 2014; 53(12): 915.

25. Beswick R, Driscoll C, Kei J, Glennon S. Targeted surveillance for postnatal hearing loss: a program evaluation. Int J Pediatr Otorhinolaryngol, 2012; 76: 1046-56.

26. Vázquez M, Iriondo M, Agut T. Poó MP, Ibañez M, Krauel $\mathrm{X}$. Follow-up programme dropouts in very low weight newborns before two years of age. An Pediatr (Barc), 2011; 74(5): 309-16. 